\title{
Speculative Fabulations for Technoculture's Generations: Taking Care of Unexpected Country ${ }^{1}$
}

\author{
Donna Haraway
}

When I first saw Patricia Piccinini's work a few years ago, I recognized a sister in technoculture, a co-worker committed to taking 'naturecultures' seriously without the soporific seductions of a return to Eden or the palpitating frisson of a jeremiad warning of the coming technological Apocalypse. ${ }^{2}$ I experienced her as a compelling storyteller in the radical experimental lineage of feminist science fiction (SF). In a SF sense, Piccinini's objects are replete with narrative speculative fabulation. Her visual and sculptural art is about worlding; i.e., 'naturaltechnical' worlds at stake, worlds needy for care and response, worlds full of unsettling but oddly familiar critters who turn out to be simultaneously near kin and alien colonists. Piccinini's worlds require curiosity, emotional engagement, and investigation; and they do not yield to clean judgments or bottom lines - especially not about what is living or non-living, organic or technological, promising or threatening. Lindsay Kelley, a graduate student in my 2004 seminar in bioart and critical theory, playing brilliantly with Still Life with Stem Cells and Young Family, awakened my passion for Piccinini's corporeal practice of ethically inquisitive fabulating in the heterogeneous media of her collaborative work habits. So I set about learning what these worlds might be like and how they invite the risk of response, of becoming someone one was not before encountering her human and non-human critters.

\footnotetext{
1 This paper was previously published in (tiernas) criaturas, catalogue of the ARTIUM exhibition of Patricia Piccinini's art, Vitoria-Gasteiz (Spain), 2007, pp. 100-107.

2 For more on naturecultures and Piccinini's Surrogate (for the Northern Hairy-nosed Wombat) (2004), see Haraway, When Species Meet.
} 


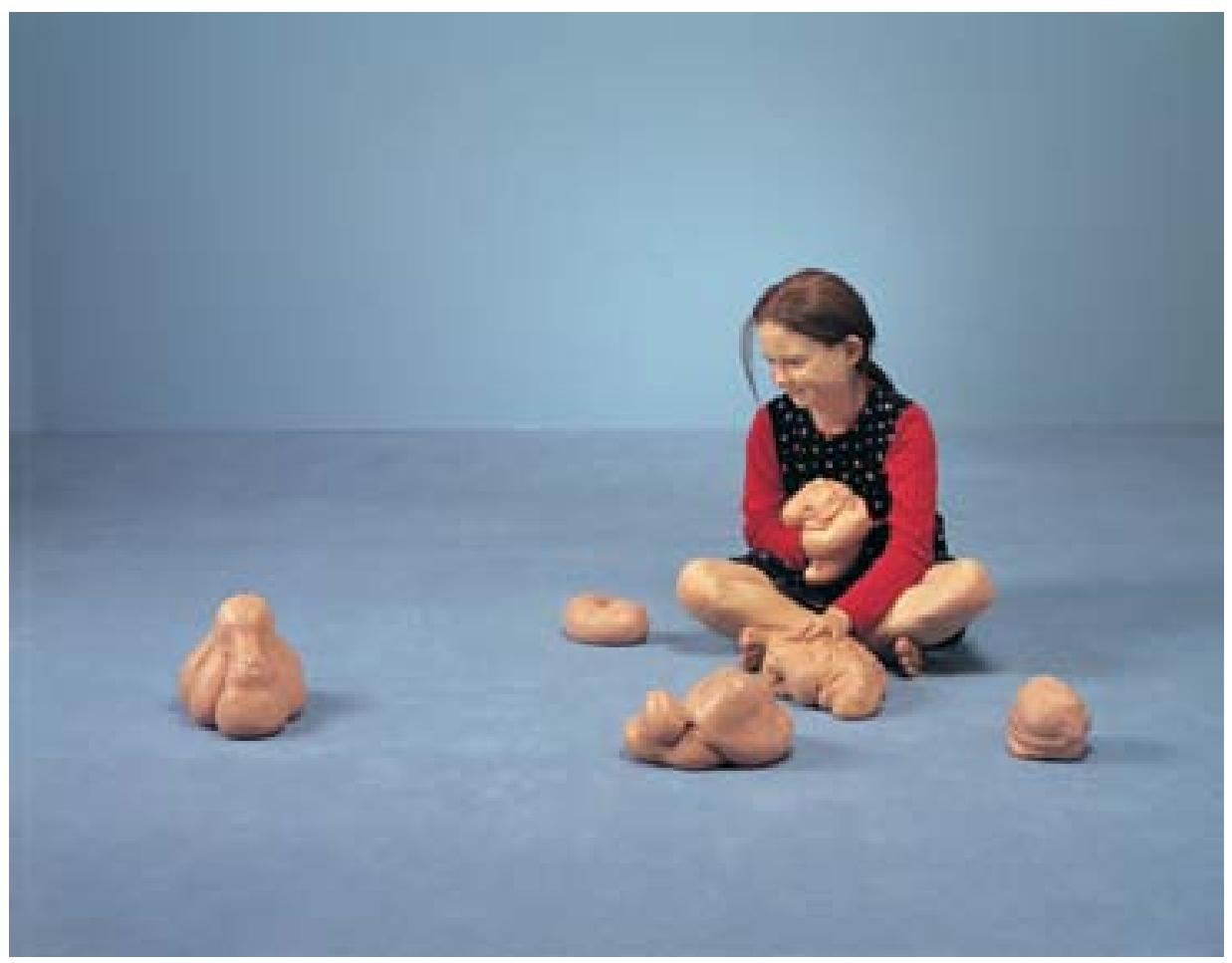

Still Life With Stem Cells

2002

Silicone, polyurethane, human hair, clothing, carpet.

Lifesize, dimensions variable

Photo: Graham Baring 


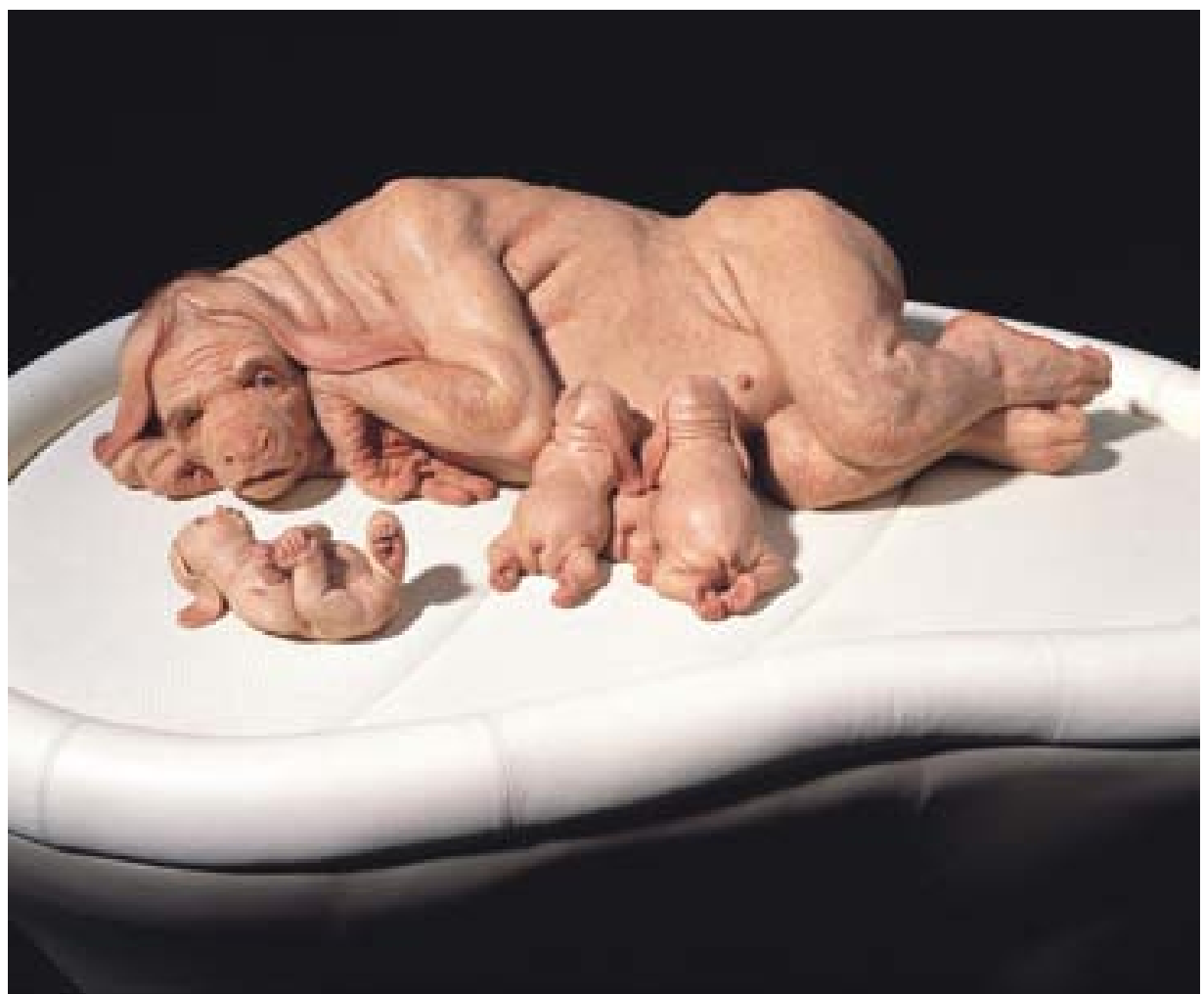

The Young Family

2002

Silicone, fibreglass, leather, human hair, plywood

$85 \mathrm{~cm}$ high $\mathrm{x} 150 \mathrm{~cm}$ long $\mathrm{x} 120 \mathrm{~cm}$ wide approx.

Photo: Graham Baring 
Piccinini's worlds are full of youngsters - including pink and blue truck babies promising to tell where grown-up trucks come from, ambiguously foetal-like transgenics in Science Story, eager if blob-ish stem cell playgroups with a girl in a polka-dot smock, Euro-Australian children paired with fabulated introduced species of indeterminate age, anamorphic motorcycle neonates in Nest, vividly coloured cyclepups, naked pink synthetic paedomorphic 'siren moles' in the $\mathrm{SO} 2$ series, and gestating wombats in the dorsal pouches of protector surrogates. She invites those willing to inhabit her worlds to dedifferentiate in order to risk bio-engineered redifferentiating as part of a queer family whose members require us to rethink what taking care of this country, taking care of these generations, might mean.

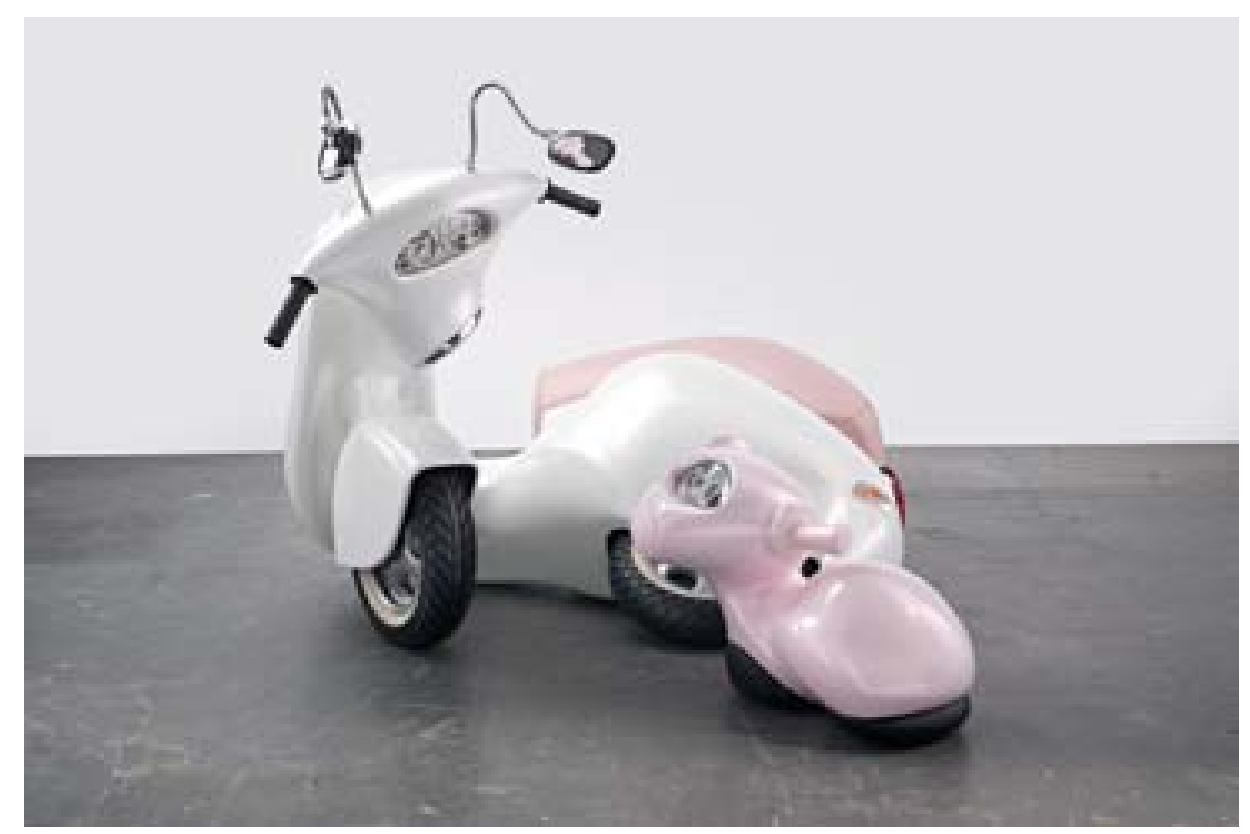

Nest

2006

fibreglass, automotive paint, leather, plastic, metal, rubber, mirror $197 \times 186 \mathrm{~cm} \times 104 \mathrm{~cm}$ high (variable)

Photo: Graham Baring 


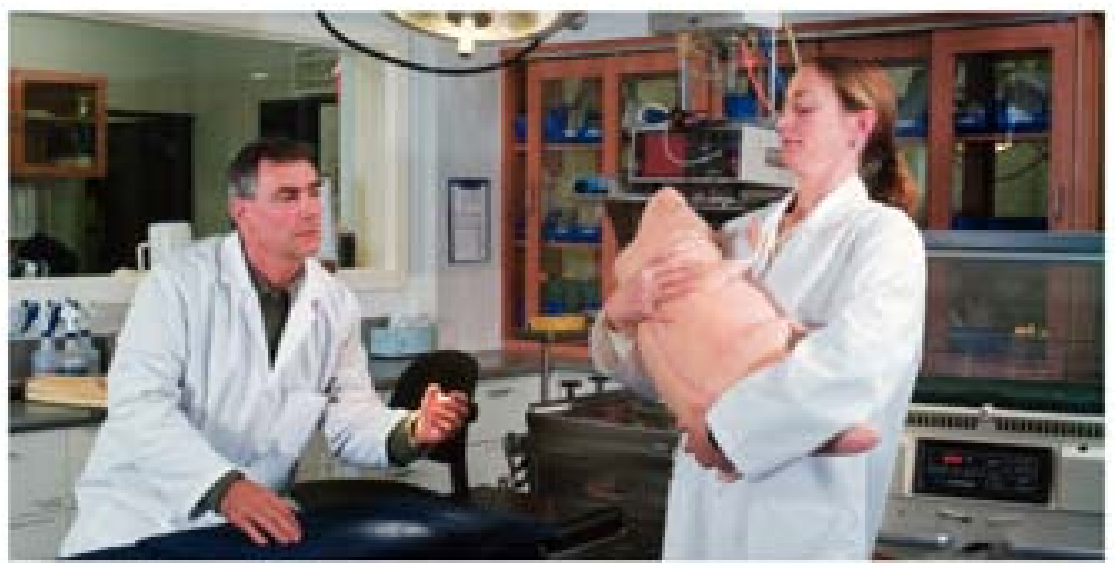

Science Story Part II: Ethical Issues

2001

Digital C-Type photograph

$100 \mathrm{~cm} \times 200 \mathrm{~cm}$

From the start, I knew Piccinini lived and worked in Australia; like me, she is the offspring of white settler colonies, their frontier practices, their ongoing immigrations, and their bad memories and troubled discourses of indigeneity, belonging, appropriation, wastelands, progress and exclusion. Twenty-first century technoscience and technoculture are nothing if not frontier practices, always announcing new worlds, proposing the novel as the solution to the old, figuring creation as radical invention and replacement, rushing toward a future that wobbles between ultimate salvation and destruction but has little truck with thick pasts or presents (Kenney). But in her sensuous sculptural and graphic stories of terran critters who were not on earth before now and whose evolutionary and ecological habitats are the installation, the mall, the website and the lab, Piccinini seems to me to be proposing not another frontier, but rather something more akin to a decolonizing ethic indebted to Australian Aboriginal practices of taking care of country and accounting for generations of entangled human and nonhuman entities. 
In this little essay, I want to think about Piccinini's art in conversation with the anthropologist Deborah Bird Rose's Reports from a Wild Country. Rose is a Euro-American who came to Australia as an ethnographer in the early 1980s to study with Aboriginal people in the Northern Territory around the Victoria River District. Since that time she has worked on land claims, collaborative documentation of sacred sites, and refiguring and enacting social and ecological justice on wounded but still vital places across Australia that must somehow collect up all of their past and contemporary inhabitants - those human and not, as well as those technological and organic. She, her Aboriginal teachers and friends, and many other Australians work to re-ground responsibility and accountability to time, generations and place in a way that might lead to ecological and social restoration and reconciliation. Rose was taught to see the difference between violently blasted places called 'the wild' and 'quiet country - the country in which all the care of generations of people is evident to those who know how to see it' (4). Across settler societies like the United States and Australia, 'violence is central both to conquest and to progress. ... We cannot help knowing that we are here through dispossession and death.... What alternatives exist for us, and what is asked of us? ... Alternatives arise unexpectedly in relationships among people and between people and place. Alternatives are entangled in the midst of the wild, and may depend on the wild even as they resist it' $(4,6)$. The crucial question is how to face settler heritage differently, to participate in decolonising generational practices, in a state of what Rose calls 'responsive attentiveness'.

To me, and I think to Piccinini, that question is especially pressing in the land I call technoculture, where the artist's critters all gestate and proliferate. I experience Piccinini to cultivate a practice of decolonizing responsive attentiveness. Could the worlds of technoculture ever come to be quiet country? It depends, Piccinini's critters suggest, on taking care of generations and doing so in alltoo-wild country like the mall, the highway, the lab and the installation. How might a speculatively fabulated SF art object help morph eroded and disowned no-places into flourishing and cared-for places?

Orientation to time must be the first consideration. Rose emphasizes that, shaped by Christian temporality, European societies 'face' the future, while the past is behind and is to be overcome, succeeded, surpassed. In that teleological, goaldirected orientation, the present is nothing but a vanishing point of transition toward what is to come, whether that be destruction or redemption. In contrast, the fundamentally non-teleological time of Aboriginal country is 180 degrees the other way around; people 'face' the past for which they bear the responsibility of ongoing care in a thick and consequential present that is also responsible to those who come behind, i.e., the next generations. Indwelling that sort of time, country is a multidimensional matrix of relationships: 'it consists of people, 
animals, plants, Dreamings, underground, earth, soils, minerals, waters, surface water, and air. ... All living things are held to have an interest in the life of the country ... those who destroy their country destroy themselves' (Rose 153-54). Furthermore, countries are not equivalent, interchangeable, abstract; country is materially and semiotically distinctive, each with its own human beings created for that country and responsible for it through the generations.

Nothing could seem less like modern 'Western' science and its future-besotted biotechnological and cyborgian global offspring, who are seemingly innocent of - and so radically destructive of-place. But Piccinini suggests something else is possible in technoculture, not to mention necessary, and I am on her side. Growing up in the presence of Piccinini's plethora of SF elder youngsters is to face the past and care for the generations with verve and ethical imagination. To show why I think that, I need to start again with Still Life with Stem Cells and Young Family, take a moment with the anatomical niceties of Leather Landscape even though its beings are absent from the Artium show, and then embrace my unsafe progenitors and offspring among the critters of the series Piccinini calls Nature's Little Helpers. As the artist's exhibition at the Venice Biennale in 2003 proclaimed, 'We are family'. Happily, this is not the world-famous heterosexual nuclear family of Christian settler imaginations, and of all-too-current national policy.

Most of Piccinini's works are premised on bioscientific practices of manipulation and alteration of living beings, of creating 'new worlds' if 'only' in art. Stem cell research, genetic engineering, cloning, bioelectronics and technologicallymediated ecological restoration and kin formation loom large. Reorienting the arrow of time, both Still Life and Young Family provoke the onto-ethical question of care for the intra- and inter-acting generations that is not asked often enough in technoculture, especially not about its own progenitors and offspring. The important question is not found in the false opposition of nature and technology. Rather, what matters is who and what lives and dies, where, when, and how? What is wild, and what quiet? What is the heritage for which technocultural beings are both accountable and indebted? What must the practices of love look like in this tangled wild/quiet country? Piccinini's essay 'In Another Life' poses the question of care in words: 'I am particularly fascinated by the unexpected consequences, the stuff we don't want but must somehow accommodate. There is no question as to whether there will be undesired outcomes; my interest is in whether we will be able to love them' (13). Replying to a questioner at her 2003 lecture at the Tokyo University of Fine Art, Piccinini laid out her large, queer, non hetero-normative view of our technocultural family: 'In my work, perhaps I am saying that whether you like them or you don't like them, we actually have a duty to care. We created them, so we've got to look after them'. Looking after 
imperfect, messy, really existing, mortal beings is much more demanding - not to mention playful, intellectually interesting and emotionally satisfying - than living the futuristic nightmare of techno-immortality.

Piccinini insists in word and object that the people of technoculture have a familial, generational duty to their failures, as well as their accomplishments. Natural or not, good or not, safe or not, the critters of technoculture make a body- and soul-changing claim on their 'creators' that is rooted in the generational obligation of and capacity for responsive attentiveness. To care is to know how to nurture quiet country through the often unexpected generations, not to point toward future utopia or dystopia. To care is wet, emotional, messy, and demanding of the best thinking one has ever done. ${ }^{3}$ That is one reason we need speculative fabulation.

The cell-blob/human-girl playgroup in Still Life with Stem Cells is neither utopian nor dystopian; it is seriously playful and so curious, inquisitive and risky. Encountering either this romp or the Young Family of mop-eared, porcine transgenics (do they exist to provide sick, wealthy humans with organs and tissues?), both the artist and visitors to the exhibit palpably run the risk of coming to care about, even to love, the fabulated blobs and the unlovely chimeric litter with a shrivel-skinned, big-rumped, heavy-lidded, all-too-humanoid mama.

Commenting on those big-headed and ungainly synthetic organisms called siren moles, such as the one on the blue car seat in the Artium exhibit's SO2 (series) Waiting for Jennifer (2000), the Sydney writer on Australian contemporary art Jacquelyn Millner concluded:

Unlike Dr Frankenstein who grew to hate his creation and suffered the consequences, Piccinini would urge us to bring an attitude of love to the products of technology, to accept our ethical mantle as creators, to take care of all our progeny, even of the artificial variety. The love she appears to propose is not of the romantic, infatuated ilk - classic technophiliabut of the familial variety, with its overtones of responsibility, ethical guidance and life-long commitment.

I would only add that Rose's understanding of Aboriginal material and ethical guidance on taking care of country insists that we learn to care for ancestors as

3 For feminist science studies thinking about matters of care, see Maria Puig de la Bellacasa, paper delivered at the Center for Cultural Studies, University of California Santa Cruz, 30 May 2007. Besides participating in the European NextGenderation webs of writing and collaboration, Puig wrote her PhD thesis at the University of Brussels with the philosopher Isabelle Stengers as her adviser. 
well as offspring. We face ancestors and progeny come after; learning how to tell time that way in technoculture would be truly revolutionary. It would mean taking the present seriously, not just passing through it to elsewhere.

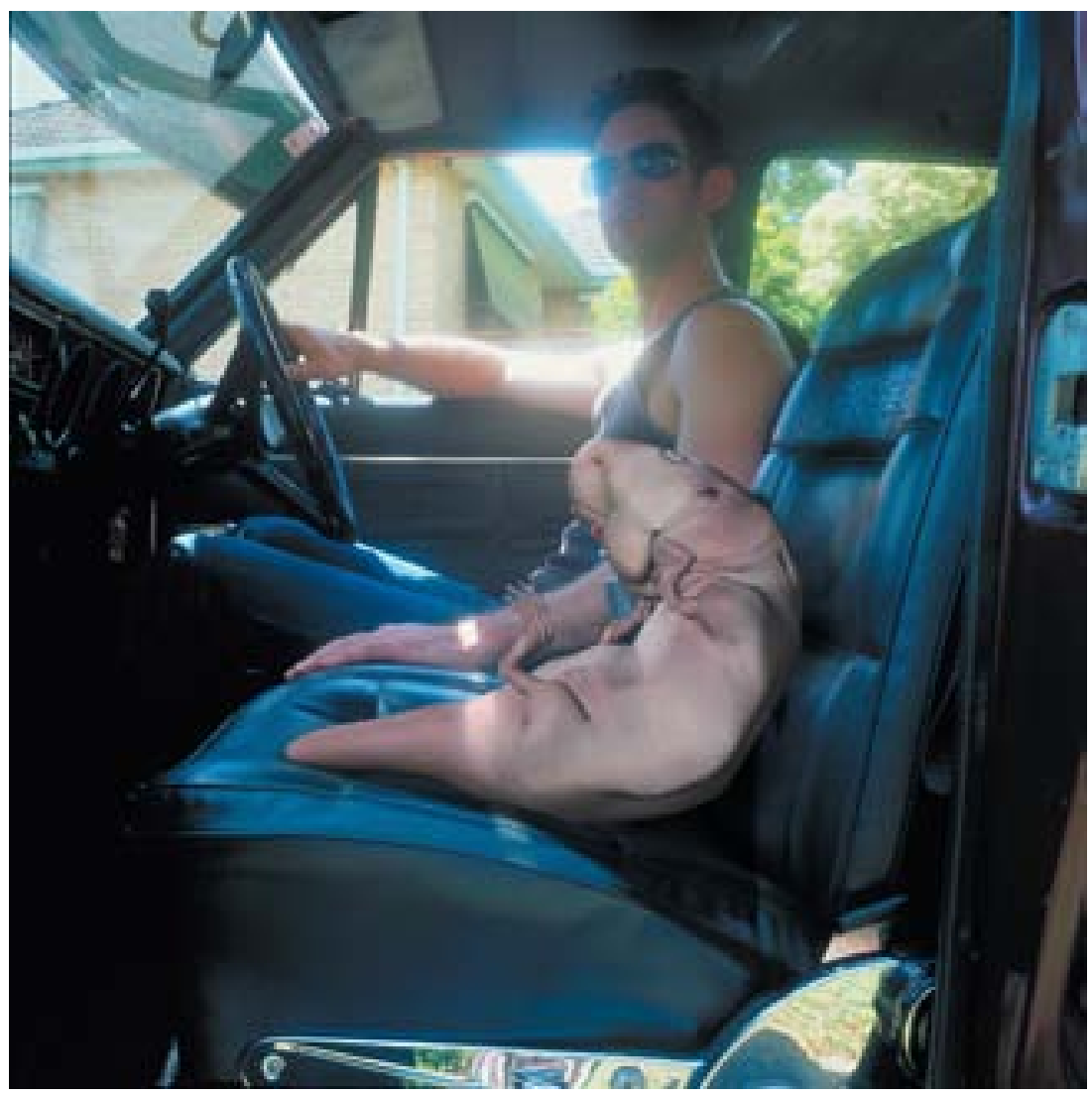

Waiting for Jennifer

2000

From the series $\mathrm{SO} 2$

Digital C-type photograph

$80 \times 80 \mathrm{~cm}$

This brings me to my favourite Piccinini critters: Nature's Little Helpers. Alerting viewers to both danger and possibility, these drawings, installations and sculptures palpably argue that the artist has fallen in love with her speculatively fabulated progeny; she has certainly made me do so. To get to Nature's Little Helpers, where I will encounter the intriguing dorsal pouches on a protector species fabulated for gestating the young of an endangered species of wombat, I mentally pass by the colony of humanoid, transgenic, African Meerkat-like beings in The Leather Landscape (2003), exhibited in 'We Are Family' at the Venice Biennale but not in the Artium show. 


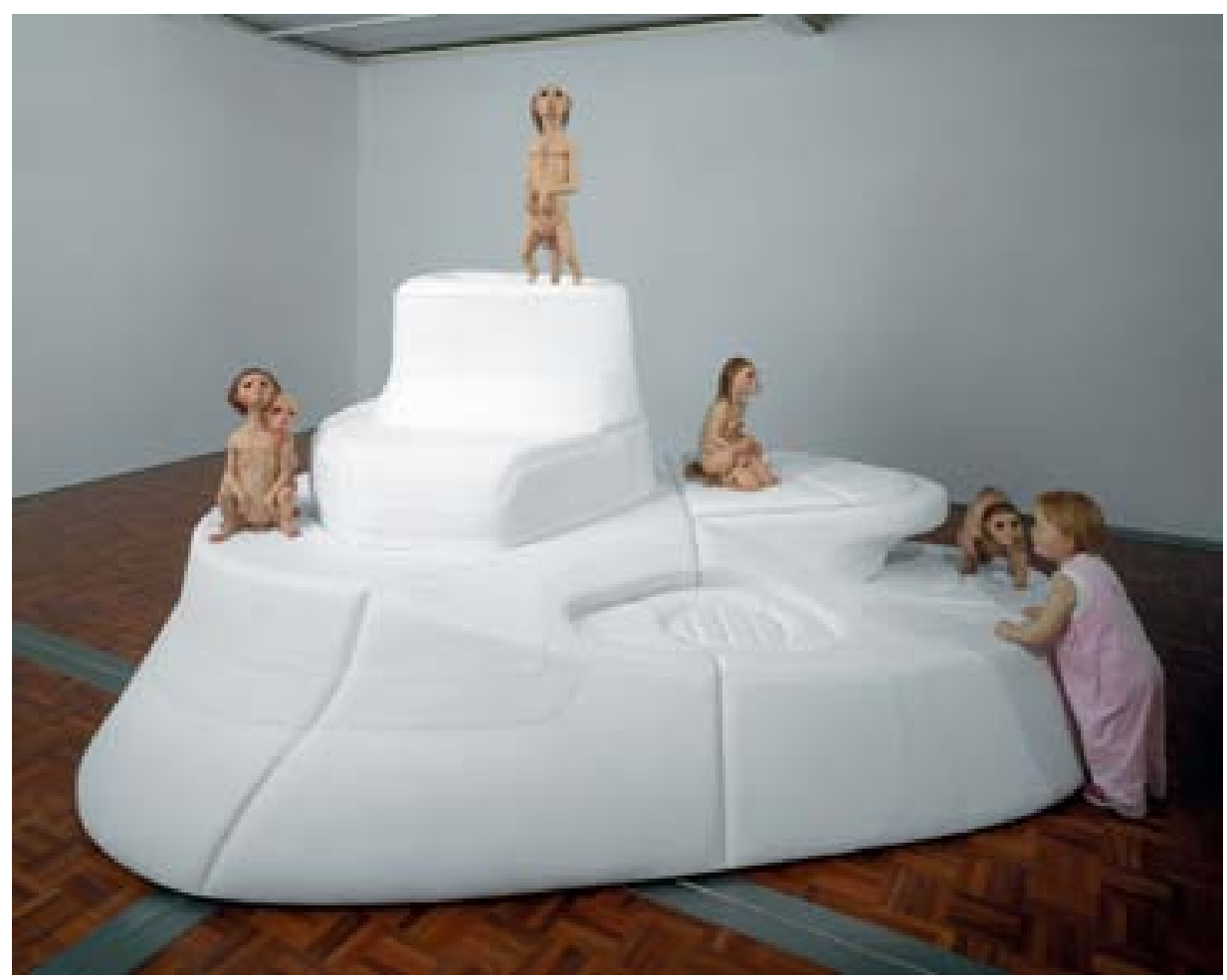

Leather Landscape

2003

Silicone, fibreglass, leather, human hair, clothing, timber $290 \times 175 \times 165 \mathrm{~cm}$ (irreg.)

What arrests me in this more-than-natural colony is not the pink-suited blond human toddler face-to-face with a fabulated potential playmate living on soft white leather in the museum space. Rather, I am struck by the four-breasted female sitting peaceably on the next level up of the pyramidal habitat, with her milk-lusty babies nestled between her legs ready to attach to her alluring array of ventral teats. 


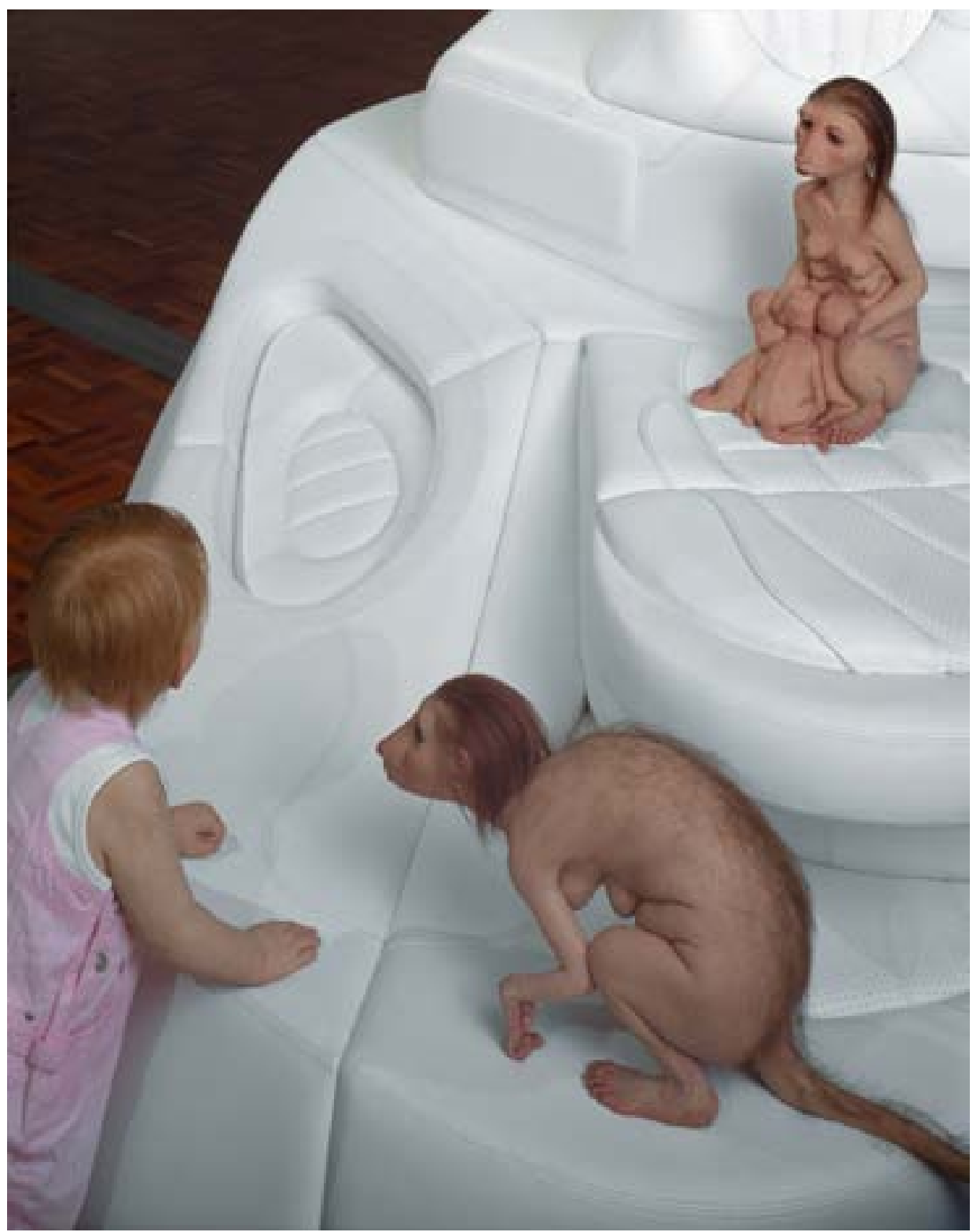

Leather Landscape

2003

Silicone, fibreglass, leather, human hair, clothing, timber $290 \times 175 \times 165 \mathrm{~cm}$ (irreg.) 
If I had not seen the critters from Nature's Little Helpers first, I might not have noticed the 'natural' feature of ventral teats on the transgenic mother in Leather Landscape, nor paused at the number four. But I did see the dorsal pouches first, and now I cannot let go of the image of the fronts and backs of progenitors and guardians all covered with organs to feed and shelter off-category offspring. I cannot let go of the capacious, inventive arrangements Piccinini makes to take care of unexpected, vulnerable, hungry progeny of whatever species, natural or not. Look what the stork brought!

With Nature's Little Helpers, Piccinini focuses her questions more on ecology and evolution than on genetic engineering or cloning, but the domains are not cleanly separated either. For one thing, the Helpers are all SF humanoids with dubious naturalcultural genealogies. In the stark heritage of destroyed human and non-human beings and blasted country, acknowledged or not, the past surges into the present and shapes possible futures just as it does in Rose's reports from a wild country. The pressing question is how to inherit, how to face, the living - and killing - past. The urgent need is to learn how to do that in order to be able to take the present seriously, in order to be able to move toward multi-species reconciliation. But in settler societies and their 'global' heirs, the category of 'endangered species' takes hold of organisms, including people, and subjects them to the ambiguous grace of salvation, specifically being saved through a regulatory and technological apparatus of ecological and reproductive management. Salvation is proposed in the time frame of barely secularized 'Western' science. Apocalypse looms; in that story the past-nature - is the time outside time and must be restored in all its innocence. That kind of time is utterly wild, i.e., outside the care of responsible generations. Thick, contingent, relational, naturalcultural history disappears once again in the dream of natural wilderness, a frontier category of the first rank in the lineage of settler societies. Prodded by Rose, I experience Piccinini's art to propose another kind of time and place for vulnerable creatures of diverse species and generations. Piccinini's art is tuned to reconciliation and taking care of always situated place and its denizens.

To do so, Piccinini introduces a bestiary of SF protector species paired with Australian officially endangered species. The speculatively fabulated protectors are not altogether reassuring, nor should they be. The settler habit of introducing species that quickly add problems to those they were supposed to solve is in the forefront of Piccinini's thinking. She remembers Australia's and Aotearoa New Zealand's naturalcultural history of introduced species, human and non-human alike, with modern examples such as the cane toad brought from the neotropics to munch repressively on the cane beetle that eats the sugar cane that gobbles up laboring people, who need the money from sugar to feed their children. She remembers the exterminist consequences of well-intentioned introductions of 
companion species - in this example, for the unintended meal; i.e., the endemic amphibians gobbled up by voracious, prolific, mobile cane toads. In addition to the fact that they were not fabulated to watch out for people, the protectors are emphatically introduced species. If they have them at all, their home worlds are elsewhere. How can one not see in Piccinini's narrative art the not always so well intentioned introductions of the settlers themselves and their exterminist consequences? The Helpers might watch out for officially endangered species, but someone will have to watch out for the protectors too-in every sense of 'watch out'.

There will be unexpected consequences. Taking care of unexpected country will be required-again and always. Reconciliation is not guaranteed; it is proffered, suggested, haltingly pictured. Any reconciliation will depend on descendents of settler worlds letting go of salvation history and instead learning to live in technoculture in something more like the time of Aboriginal country, facing ancestors of many kinds and responsible for those who come after. Technocultural people must study how to live in actual places, cultivate practices of care, and risk ongoing face-to-face encounters with unexpected partners. Well-tuned people have to be present in country for it to flourish; thus, there will be no perfection, but there can be ongoing and effective care that stays alert to many sorts of history. This kind of time and place is utterly contemporary; i.e., committed to a flourishing present, not a present that is only a pivot between past and future. Learning how to live in a flourishing present is indebted to Aboriginal practices and ideas, but not in the mode of colonial or postcolonial settlers finding salvation in the indigenous to heal the scars of the modern and technological. That way of understanding reconciliation completely misses the point about another conception of time and place, another way to face histories, or what feminist theorist Katie King calls 'pastpresents'. The unbridgeable dichotomy between the traditional and the modern is as much a frontier myth as the cordon sanitaire between nature and culture or the organic and the technological.

What is certain in Piccinini's world is that nature and culture are tightly knotted in bodies, ecologies, technologies and times. For example, dependent on companion-species relations among gum trees, a kind of possum, and their feathered selves in order to get their sugary meals of oozing sap, Golden Helmeted Honeyeaters, or HeHos, are tiny brightly coloured birds living in Victoria. Their survival is threatened by ignorant or greedy humans encroaching on their places and cutting down their gum trees. Their living arrangements need people who know how to recognize and live with HeHo ecologies. Only fifteen breeding pairs are known to survive. Piccinini invented a protector for $\mathrm{HeHos}$ called the Bodyguard. Armored adult Bodyguards look fearsome, with their serious canine teeth and imposing threat postures. Several photographs in the Artium exhibit 
picture the Bodyguard and HeHos in their complex naturalcultural ecologies and economies with contemporary people (Arcadia, Getaway, Roadkill, Thunderdome). Look closely at the Bodyguard sitting beside young Alice in the graphite drawing in the Artium exhibit. Both the human and off-human critters are using cell phones; their speculatively playful conversation is corporeally a tangle of the organic and technological. Then look at the infant Bodyguard sitting with baby Hector in the graphite drawing; these youngsters do not find each other strange; they are coeval, in shared time. They are full of the promise of reconciliation if their parents can learn to face the past in the present. Unlike the HeHos and the Aboriginal people historically responsible for taking care of country, both sets of parents for the youngsters in the drawing - those for the Bodyguards and those for Hector-are introduced settler species in Australia. That fact implies a long and steep learning curve for knowing how to recognize and care for place and time.

The ecological, evolutionary and assisted-reproduction narratives of Nature's Little Helpers all pulsate with pastpresent lives and the ongoing care they demand. Endangered species by legal definition signal the threat of the final loss of 'heritage'. But that global-speak, settler-nation kind of heritage culture or heritage nature is not what Piccinini's Helpers are concerned with, as I experience these storied drawings, photographs and installations. The Helpers seem to have a much more relational and mundane task on their hands. Without the supposed comfort of attending to their own 'natural' offspring ('natural' in their case would mean transgenic if not science fictional progeny), the introduced protectors' job seems to be to parent their unsafe, endemic, and toofew xeno-specific charges. The Helpers' job is to nurture these charges into full contemporary naturalcultural sociality, to locate them in a flourishing present replete with its expected, unexpected and ontologically heterogeneous beings. To parent is to instruct, guard, carry, nurture and finally let go. The principal charges of the Helpers whom Piccinini has introduced so far are HeHos, Leadbeater's Possums and Northern Hairy-nosed Wombats, not human beings, a point people would do well to remember in the presence of these protectors.

Just look at The Embrace (2005) in the Artium exhibit for clarity on this matter. Reminiscent of images of the parasitizing monster from the film series Alien, the Progenitor for the Leadbeater's Possum glues its whole self alarmingly onto the face of a human woman. Perhaps she looked too closely. Perhaps she had no respect. She certainly did not face in the right direction and may never be able to correct her error. 


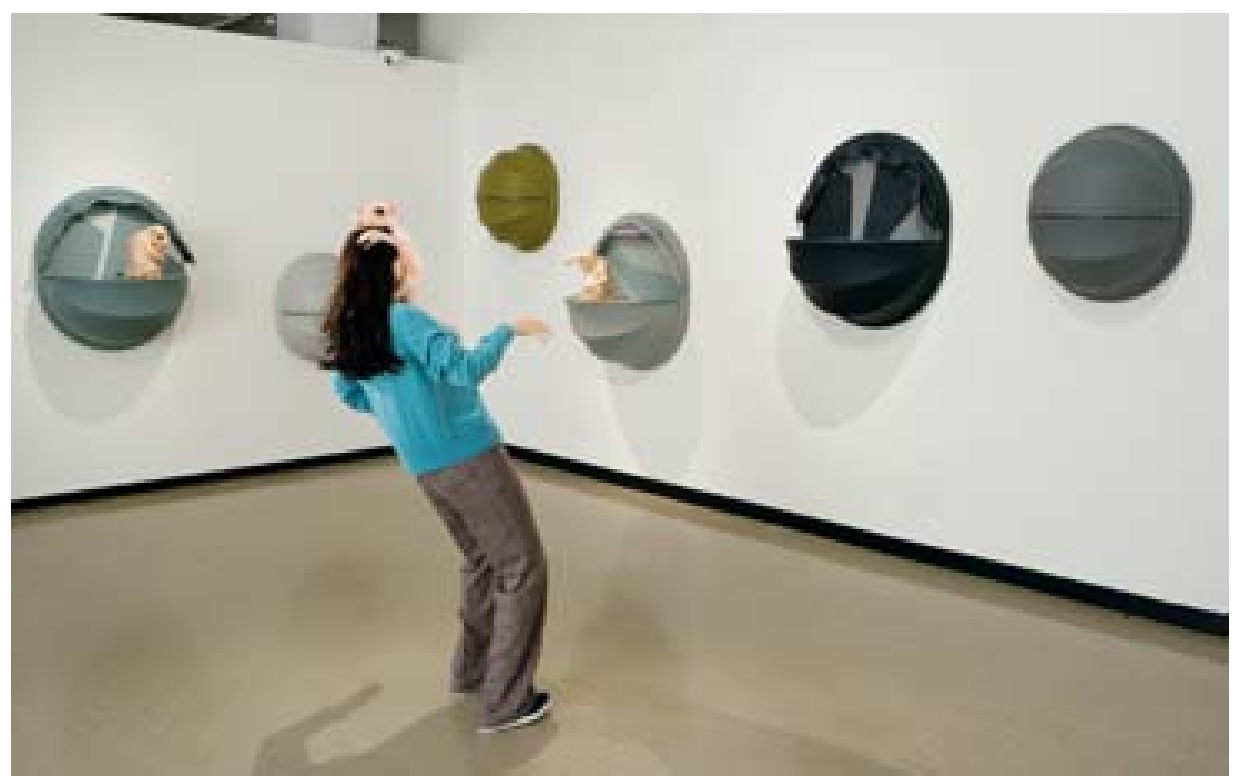

The Embrace

2005

Silicone, fibreglass, leather, plywood, human hair, clothing variable dimensions

Photo: Guy Robinson

But in this exhibit, we see too the other side of the protectors - their unaccountable interest in and seeming openness to those who come behind the settlers who imposed a frontier naturalcultural ecology and frontier knowledges, including so much of technoscience. The progeny of endangered species - those who will exist in generations past, present and future because of their SF protectors' effective care-will meet human youngsters descended from the wild settler species who are willing to learn what contemporary quiet country might still be, including a technoscience committed to flourishing pastpresents. Nurtured by their teachers, alien and aboriginal, these youngsters might yet track a path to reconciliation in their reports from a wild country. 


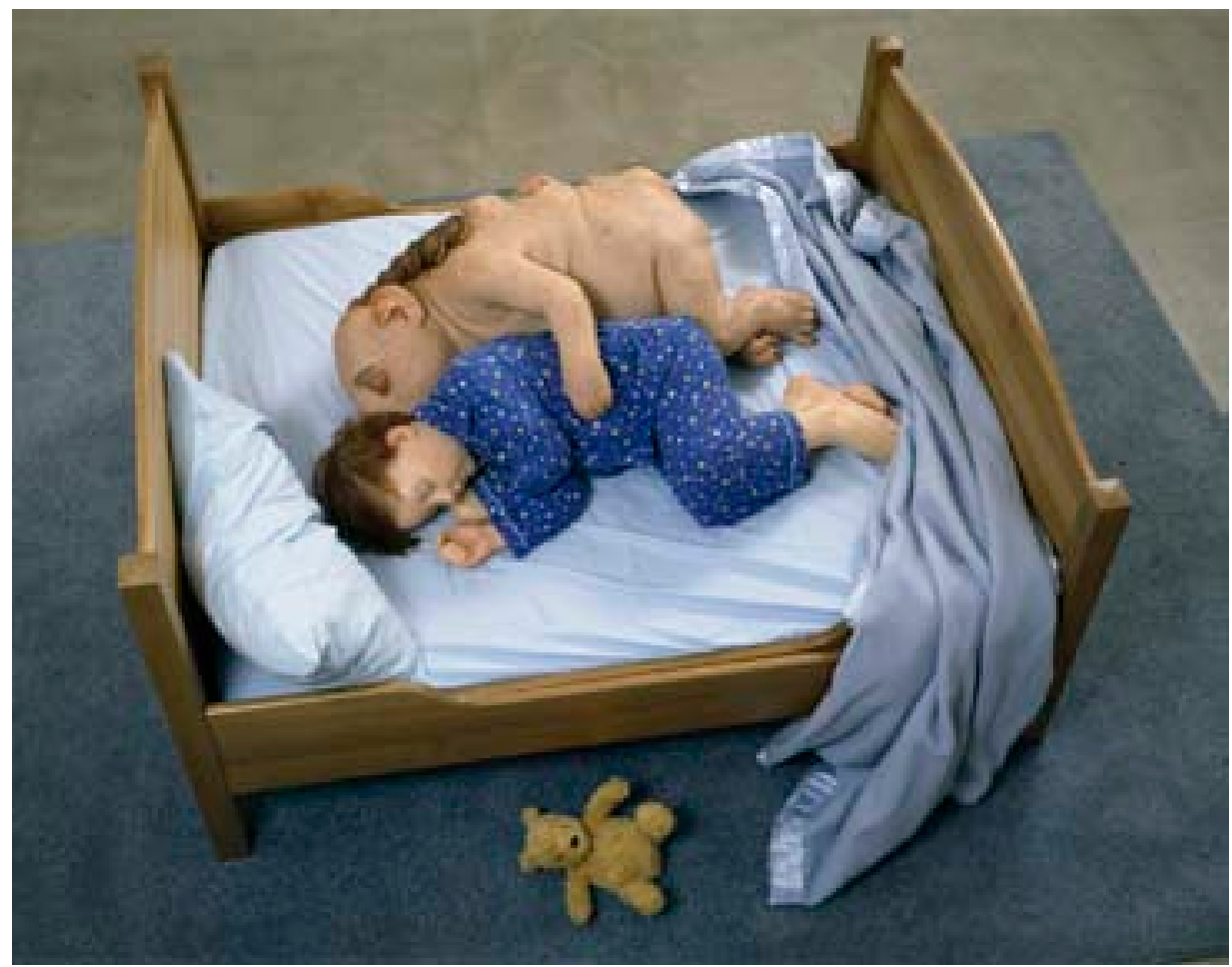

Undivided

2004

silicone, fibreglass, human hair, flannelette, mixed medium

$101 \times 74 \times 127 \mathrm{~cm}$

Photo : Graham Baring

Look closely at the blue-sheeted bed with the life-size figures made of silicone, hair and acrylic resin in Undivided (2004). A settler-descended human child sleeps spooning with an adult Surrogate for the Northern Hairy-nosed Wombat. The scene is peaceful; the Surrogate seems utterly unthreatening, the human child embraced tenderly. Walk around to the back of the sleeping Surrogate to see the two rows of drawstring dorsal pouches running along the Helper's spine, six in all. Each pocket shelters an immature marsupial wombat, with the earliest still-foetal stages, no bigger than a jelly bean, gestating at the anterior end and the ready-to-face-the-world older joey poking out of the posterior pocket. That furry youngster seems likely to pop out of the pouch by morning to meet the girl before the Surrogate even wakes up. That meeting could surprise all the parents and guardians in these off-category species assemblages. 


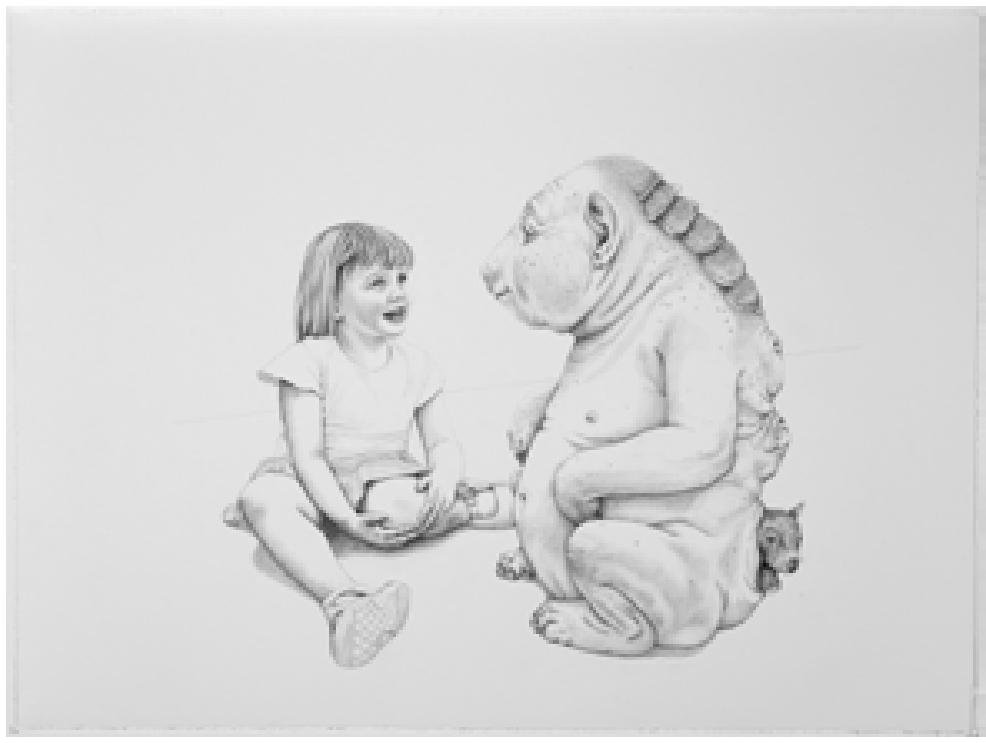

\section{Laura}

2006

Graphite on paper

$57 \times 77 \mathrm{~cm}$

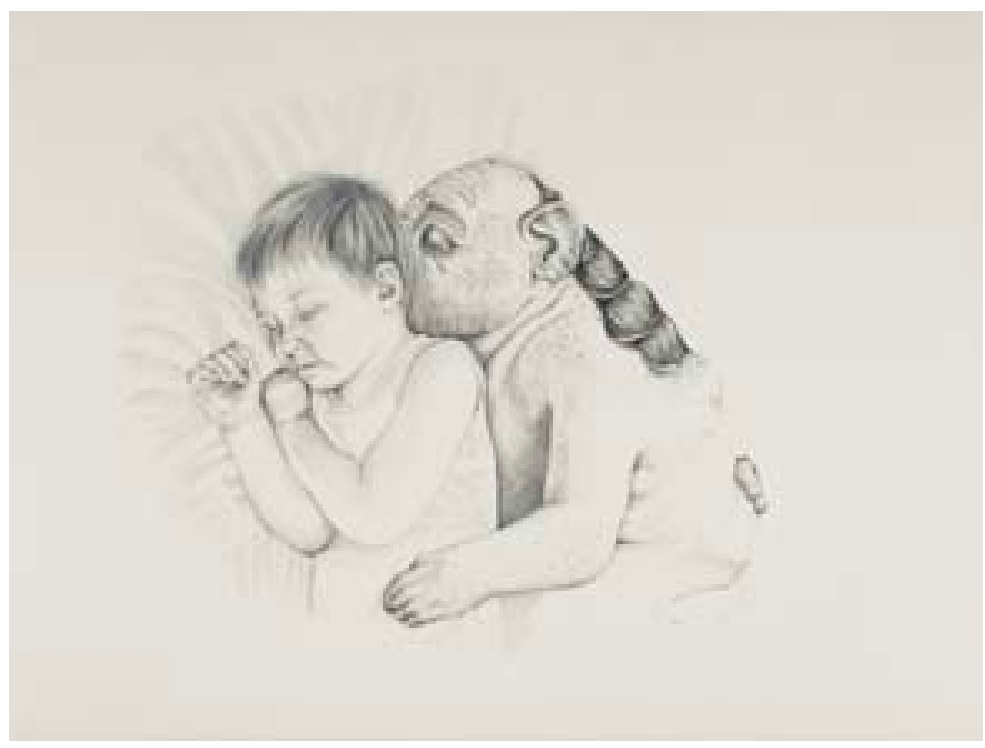

Leo

2006

Graphite on paper

$57 \times 77 \mathrm{~cm}$ 
The two drawings of human children and Surrogates in the Artium exhibit, Laura and Leo, also seem to portray benign companions. Still, I know that human babies often hurt the other critters they play with. I trained with my dogs and children on loan from my graduate students, so that the canids might tolerate such exploratory excesses by badly coordinated, unaccountable, tiny hominids unwisely endowed too early in their development with grasping hands. Are the Surrogates so well instructed? Why should they be? The adult Surrogates and the children are awfully close, maybe too close for a human child and an alien guardian species.

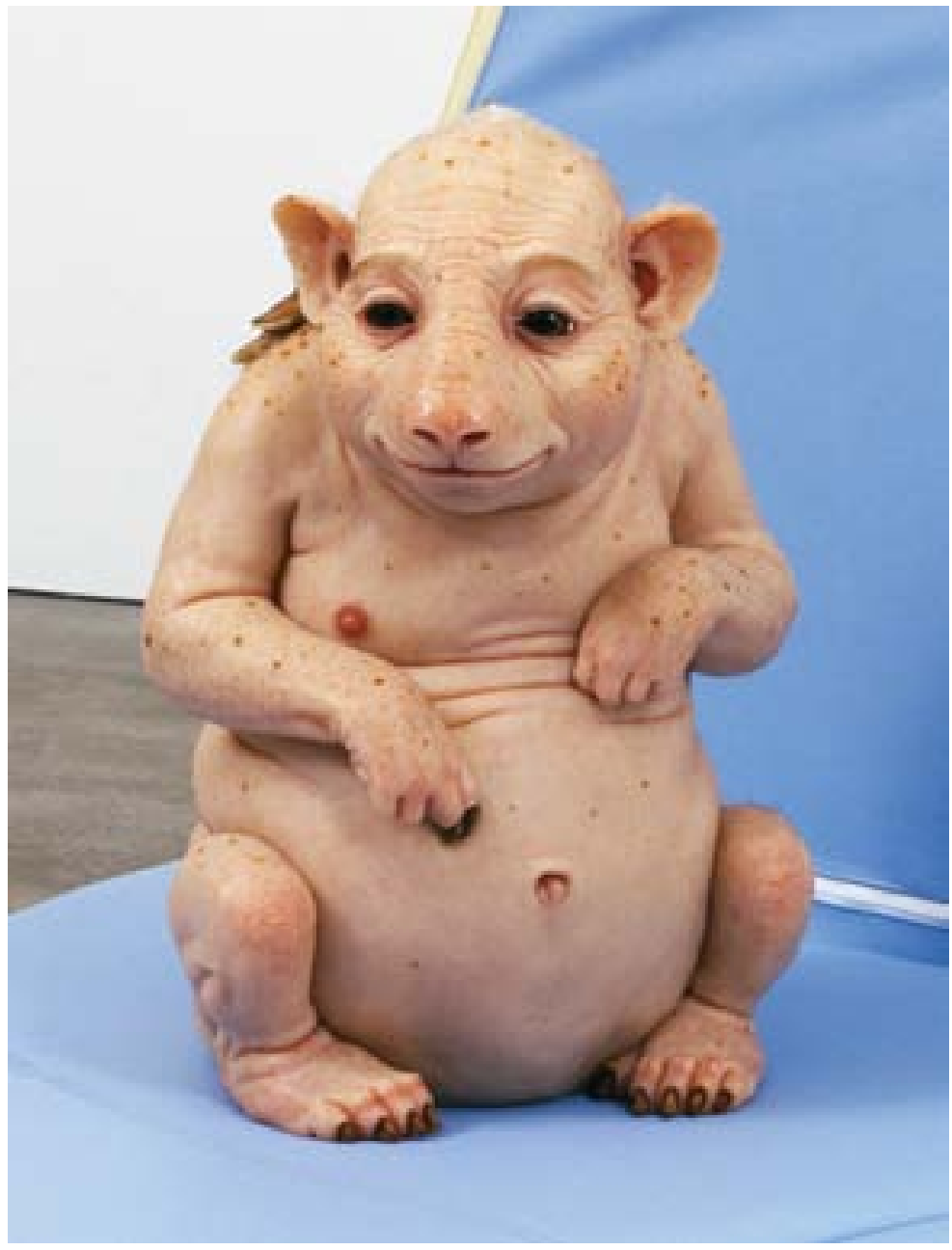

Surrogate

2005

Silicone, fibreglass, leather, plywood, human hair

$103 \mathrm{~cm} \times 180 \mathrm{~cm} \times 306 \mathrm{~cm}$

Photo: Guy Robinson 
The appealing, full-frontal Surrogate in colour on the cover of the Wellington exhibition catalogue, In Another World, does not calm my anxiety or Piccinini's. The creature's ventral surface does sport a proper navel, indicating some kind of mammalian kinship, however reconfigured in SF technochimeras and however foreign to the non-uterine gestational needs of marsupial wombats. The Surrogate was not fabulated to be a protector for Homo sapiens, after all, but for Lasiorhinus kreftii, whose habitats and associates have been blasted by the very species introduced by Leo and Laura's ancestral kin, if not by the kin directly.

I am not sure what Queensland's indigenous peoples call or called Northern Hairy-nosed Wombats, although 'Yaminon' is an Aboriginal name (whose?) for these animals that appears in global internet conservation websites today without discussion of the human/nonhuman historical naturecultures that generated that name. I am even less sure what names different Aboriginal peoples might give the dorsally armoured Surrogate. The young certainly come behind! The term 'wombat' itself comes from the Eora Aboriginal community that lived around the area of modern Sydney. ${ }^{4}$ But whatever the proper names, the Surrogates could reasonably decide that Laura, Leo and the girl in Undivided do not fall under their writ of protection if the young hominids get unruly with the wombats, intentionally or not.

Let us consider for a moment a contemporary adult Northern Hairy-nosed Wombat, sometimes called the bulldozer of the bush, as she burrows intently in the dry woodland floor of the Ebbing Forest National Park in central Queensland. Keeping the dirt out, the female's backward-facing pouch shelters a youngster attached to a teat on her belly. Including perhaps only 25 breeding females in the early years of the twenty-first century, with adults weighing between 55 and 90 pounds, these roguish but vulnerable marsupials are among the world's rarest large mammals. ${ }^{5}$ It might seem tragically easy to count these wombats - if only the nocturnal and crepuscular, generally solitary and secretive critters would show themselves to the census takers. Working with the Queensland wombat for over ten years, Dr. Andrea Taylor of Monash University in Melbourne 'has developed a low disturbance genetic technique to census the wombat population. Wombat hair is collected on sticky tape strung across wombat burrows and DNA in the follicle is used to identify the sex and the "owner" of the hair' (Yaminon). In her non-invasive and smart technique, I consider Taylor to be practicing care. Living endangered means living in technoculture; it is a condition of flourishing - or not - on earth now for most critters. Living well in technoculture is part of the obligation of taking care of unexpected country.

$4<$ http://en.wikipedia.org/wiki/Wombat> Accessed 9 Dec. 2010.

5 The Northern Hairy-nosed Wombat can be tracked through the Wombat Information Center, <www. wombania.com>; BIRD <http://bird.net.au/bird/index.php?title=Yaminon >; and Flannery and Kendall. 
However, all is not well in the tiny patch of these wombats' remaining patch of earth. Piccinini knows that the African buffel grass planted for European cattle in the white settler colony out-competes the native grasses on which the wombats depend and that the threatened wombats contend for food and habitat with cattle, sheep and rabbits. These marsupials also endure predation by dingoes - mammals dating from much earlier introductions, who have unstably achieved ecological charismatic macrofauna status today after a lamentably unfinished career as vermin to EuroAustralians and a deep-and with great difficulty, ongoing - history as companion species to Aboriginals. Yet the modern rehabilitated nationalist dingoes, even after the cattle have been evicted and the buffel grass discouraged in the work of ecological restoration, have to be fenced out of the patch of Queensland semi-arid grassland and woodland that is the only place left where Northern Hairy-nosed Wombats burrow and dine.

But then, Piccinini knows, living beings in knotted and dynamic ecologies are opportunistic, not idealistic; and it is not surprising to find many native species flourishing in both new and old places because of the resources provided by interlopers from other lands and waters. Think of the kookaburras, displaced from their own former ranges, eating introduced pest snails and slugs alongside European starlings. Piccinini knows, in short, that introducing species (from another watershed, another continent, or another imagination) is often a worlddestroying cut, as well as sometimes an opening to healing or even to new kinds of flourishing. ${ }^{6}$ Piccinini's fabulated companion species to endangered species may be one more handy newcomer, among many, rather than a destructive invader, among many - or they may be both, the more usual course of things.

The crucial question has to be not 'are they original and pure (natural in that sense)?' but rather 'what do they contribute to the flourishing and health of the land and its critters (naturalcultural in that sense)?' That question does not invite a disengaged 'liberal' ethics or politics, but requires examined lives that take risks to nurture some ways of getting on together flourish and not others. With their generally positive attitudes to animals Europeans have disparagingly called feral, Australian Aboriginal peoples have tended to evaluate what westerners call 'species assemblages', new and old, in terms of what sustains the human/non-human, storied, changing and lived world that in English is called country. As feminist science studies scholar Karen Barad put it for ears tuned to western philosophy and science: 'Embodiment is a matter not of being specifically situated in the world, but rather of being in the world in its

6 For the shaping of 'new natures' composed of the mixed native/introduced species assemblages of every place on earth by the twenty-first century, see the controversial work by the Australian Tim Low (The New Nature). For integration of Low's approaches with science studies, sociology, colonial and postcolonial cultural studies, and considerations of animal wellbeing from both ecological and rights perspectives, see Adrian Franklin; the kookaburra example is on p. 230. 
dynamic specificity. ... Ethics is therefore not about right response to a radically exterior/ised other, but about responsibility and accountability for the lively relationalities of becoming of which we are a part' $(377,393)$.

That brings us back to the Surrogates. Look again at the three pairs of gestational pouches run down the spine of the protector companion species, nurturing three stages of wombat development.

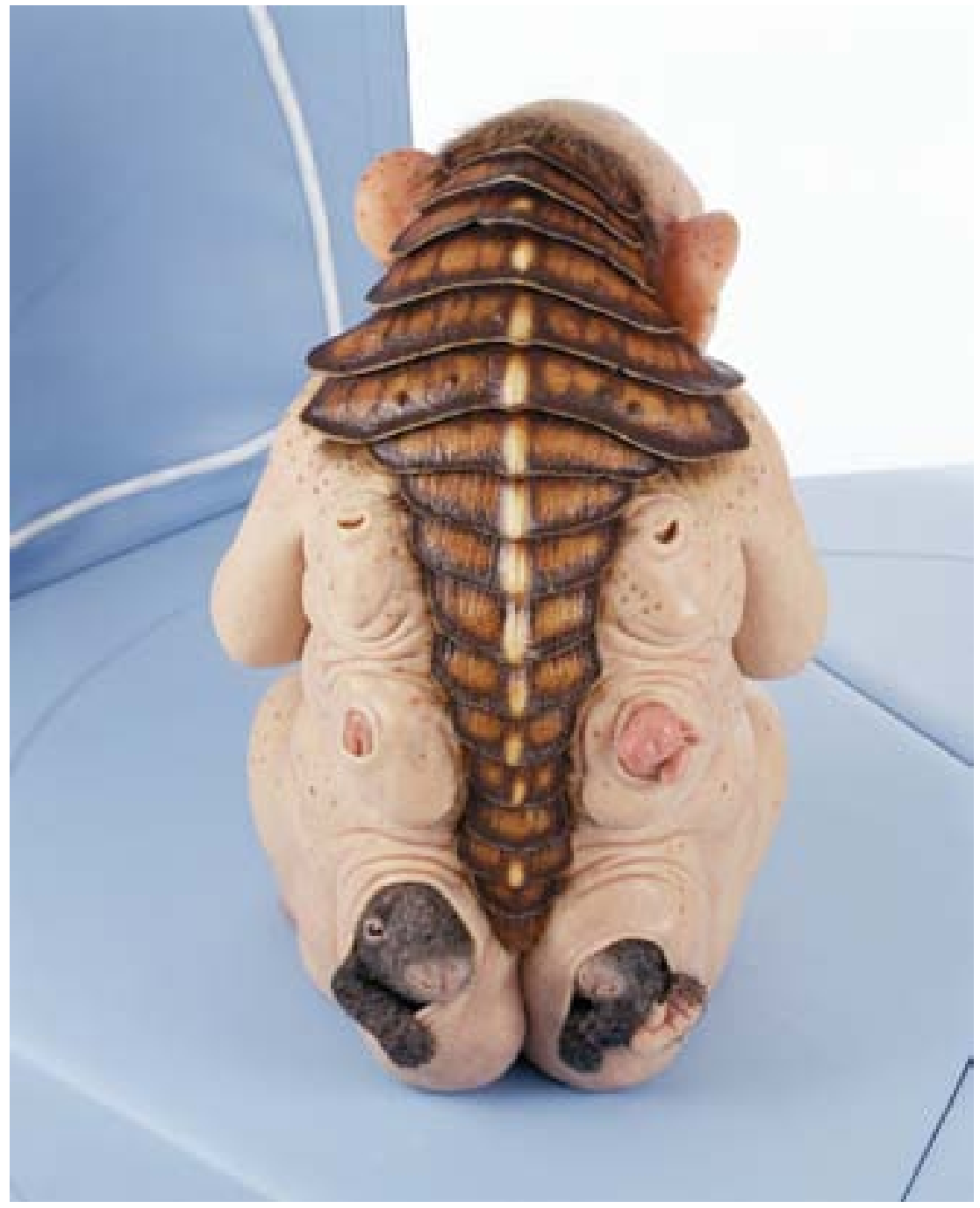

\section{Surrogate}

2005

Silicone, fibreglass, leather, plywood, human hair $103 \mathrm{~cm} \times 180 \mathrm{~cm} \times 306 \mathrm{~cm}$

Photo: Guy Robinson 
Aligned with that of other marsupials like the red kangaroo, Surrogate wombat reproduction seems to be run on 'just-in-time' principles for stocking embryos on the gestating body. Just out of the birth canal and plucked from the hairs of its wombat mama's belly while struggling up to crawl into a pouch to finish making a wombat, a barely formed embryo surely inhabits the Surrogate's top pouch. Attached to a teat? Does the Surrogate have teats in those odd sphincterringed, drawstring pouches? How not? Normal Northern Hairy-nosed Wombats have only two teats in their single, backward-facing pouch, so they can't handle three young out of the body at once, and they give birth to only one young at a time, once a year. Joeys stay in the pouch eight to nine months. But if they are like kangaroos, these wombats could have arrested embryos ready to speed up their life course if the senior joey dies - or is disappeared by aliens. Northern Hairy-nosed Wombats like to have their babies in the rainy season, and getting a replacement joey into the pouch too late, when the succulent grasses are drying out, would not bode well for that reproductive cycle anyway. Maybe the Surrogates pluck just-emerged and still foetal joeys from wombat females and put them in their own pouches, thus forcing the wombats to get another embryo out of their body sooner and multiplying the numbers of young who can be raised in a season? This would not be the first time that forced reproduction was employed as an evolutionary and ecological rescue technology. Ask any tiger in a Species Survival Plan ${ }^{\mathrm{TM}}$ database. I am reminded that only about 25 breeding female Northern Hairy-nosed Wombats live on planet Earth to gestate the young of their species. Being female in such a world never comes without paying the price of value. No wonder Piccinini is suspicious, as well as open to another world. Unexpected country will be full of surprises, good and bad, even as it is fully webbed in pastpresents.

The middle rung of Surrogate pouches houses more developed but still hairless baby wombats; they are far from ready to explore the outside world. A teat, a pouch, and a vigilant Surrogate's armoured spine are all that are required for now. The third rung of pouches holds mature furry baby wombats, and we see in Undivided that one is ready to crawl out of the pocket to begin its risky encounters in a wider world. For a few months, this joey can leap back into the pouch when things get too scary and supplement grass with milk; but even the best wombs or pouches, alien or native, give time-limited protection.

I'd love to call the Surrogate 'queer' and let it go with a celebratory frisson that comes so cost-free to those not made to inhabit the category, but I am sure Piccinini would wince if I tried to get away with that. The Surrogate remains a creature that nourishes indigestion; i.e., a kind of dyspepsia with regard to proper place and function that queer theory is really all about. The Surrogate is nothing if not the Mutter/matter of gestation out of place, a necessary if not sufficient cut into the female-defining function called reproduction. To be out 
of place is often to be in danger and sometimes also to be free, in the open, not yet nailed by value and purpose, but full of pastpresents. The point for me in Piccinini's Nature's Little Helpers is parenting, not reproducing. Parenting is about caring for generations, one's own or not; reproducing is about making more of oneself to populate the future, quite a different matter.

There is no fourth rung of guarded gestation. The human and wombat youngsters will find each other soon. Then, what the world of companion species might become is open. The past has not laid enough ground for optimism concerning relations between white settler humans and wombats. Yet the past is far from absent or without rich offerings for reconciliation. The past, present and future are all very much knotted into each other, full of what we need for the work and play of naturalcultural restoration: less deadly curiosity, materially entangled ethics and politics, and technical and organic well being. Experienced together, Rose's writing and Piccinini's art tell about attention to alien and native beings linked in learning how to take care of unexpected country, in alliance with those called traditional owners of the land who see better the difference between wild and quiet because they face those who came before and care also for those who come behind, in all their demanding and unfinished kinds.

Donna Haraway is Distinguished Professor Emerita in the History of Consciousness Program at the University of California at Santa Cruz. She is the author of many books and widely read essays, including When Species Meet (2008), The Companion Species Manifesto (2003) and Modest_Witness@Second_ Millennium.FemaleMan_Meets_OncoMouse (1997).

\section{Works Cited}

Barad, Karen. Meeting the Universe Halfway: Quantum Physics and the Entanglement of Matter and Meaning. Durham, Duke UP, 2007.

Flannery, Tim and Paula Kendall. Australia's Vanishing Mammals. Sydney: R.D. Press, 1990.

Franklin, Adrian. Animal Nation: The True Story of Animals and Australia. Sydney: U of New South Wales P, 2006.

Haraway, Donna J. When Species Meet. Minneapolis: U of Minnesota P, 2008. 
Kenney, Martha. 'Frontier Epistemologies.' Paper presented to GeoFeminisms II: Phylogeographies, History of Consciousness and Anthropology Departments, University of California at Santa Cruz, June 2007.

King, Katie. 'Pastpresents: Knotted Histories under Globalization.' NatureCultures: Thinking with Donna Haraway. Ed. Sharon Ghamari-Tabrizi. Cambridge, MA: MIT Press, forthcoming.

Low, Tim. The New Nature: Winners and Losers in Wild Australia. Sydney: Penguin, 2002.

Millner, Jacquelyn. 'Patricia Piccinini: Ethical Aesthetics.' Artlink $2001<$ http:// www.patriciapiccinini.net/essay.php/?id=4> Accessed 9 Dec. 2010.

Piccinini, Patricia. 'In Another Life.' Exh. cat. In Another Life, City Gallery, Wellington, New Zealand, 19 Feb.-11 Jun. 2006. Wellington: City Gallery, 2006.

Rose, Deborah Bird. Reports from a Wild Country: Ethics for Decolonisation. Sydney: U of New South Wales P, 2004.

Yaminon Defense Fund. 'Gallery.' <http://www.yaminon.org/gallery.html> Accessed 9 Dec. 2010. 